\title{
Deformation of Network Connectivity in the Inferior Olive of Connexin 36-Deficient Mice Is Compensated by Morphological and Electrophysiological Changes at the Single Neuron Level
}

\author{
Chris I. De Zeeuw, ${ }^{1}$ Edilzh Chorev, ${ }^{2}$ Anna Devor, ${ }^{2}$ Yait Manor, ${ }^{3}$ Ruben S. Van Der Giessen, ${ }^{1}$ Marcel T. De Jeu, ${ }^{1}$ \\ Casper C. Hoogenraad, ${ }^{1}$ Jan Bijman, ${ }^{1}$ Tom J. H. Ruigrok, ${ }^{1}$ Pim French, ${ }^{1}$ Dick Jaarsma, ${ }^{1}$ Werner M. Kistler, ${ }^{1}$ \\ Carola Meier, ${ }^{4}$ Elisabeth Petrasch-Parwez, ${ }^{4}$ Rolf Dermietzel, ${ }^{4}$ Goran Sohl, ${ }^{5}$ Martin Gueldenagel, ${ }^{4}$ Klaus Willecke, ${ }^{5}$ and \\ Yosi Yarom ${ }^{2}$ \\ ${ }^{1}$ Department of Neuroscience, Medical Faculty, Erasmus MC, 3000DR Rotterdam, The Netherlands, ${ }^{2}$ Department of Neurobiology, Institute of Life \\ Sciences, Hebrew University, Jerusalem 91904, Israel, ${ }^{3}$ Department of Life Sciences and Zlotowski Center for Neuroscience, Ben-Gurion University, Beer- \\ Sheva 84105, Israel, ${ }^{4}$ Department of Neuroanatomy and Molecular Brain Research, Institute of Anatomy, Ruhr-University Bochum, D-44801 Bochum, \\ Germany, and Institute of Genetics, Division of Molecular Genetics, University of Bonn, 53117 Bonn, Germany
}

\begin{abstract}
Compensatory mechanisms after genetic manipulations have been documented extensively for the nervous system. In many cases, these mechanisms involve genetic regulation at the transcription or expression level of existing isoforms. We report a novel mechanism by which single neurons compensate for changes in network connectivity by retuning their intrinsic electrical properties. We demonstrate this mechanism in the inferior olive, in which widespread electrical coupling is mediated by abundant gap junctions formed by connexin 36 (Cx36). It has been shown in various mammals that this electrical coupling supports the generation of subthreshold oscillations, but recent work revealed that rhythmic activity is sustained in knock-outs of $\mathrm{Cx} 36$. Thus, these results raise the question of whether the olivary oscillations in Cx36 knock-outs simply reflect the status of wild-type neurons without gap junctions or the outcome of compensatory mechanisms. Here, we demonstrate that the absence of $\mathrm{Cx} 36$ results in thicker dendrites with gap-junction-like structures with an abnormally wide interneuronal gap that prevents electrotonic coupling. The mutant olivary neurons show unusual voltage-dependent oscillations and an increased excitability that is attributable to a combined decrease in leak conductance and an increase in voltagedependent calcium conductance. Using dynamic-clamp techniques, we demonstrated that these changes are sufficient to transform a wild-type neuron into a knock-out-like neuron. We conclude that the absence of $\mathrm{Cx} 36$ in the inferior olive is not compensated by the formation of other gap-junction channels but instead by changes in the cytological and electroresponsive properties of its neurons, such that the capability to produce rhythmic activity is maintained.
\end{abstract}

Key words: gap junction; electrotonic coupling; cerebellum; motor coordination; dynamic clamp; inferior olive; ultrastructure; connexins

\section{Introduction}

Gap junctions, the morphological correlate of electrical transmission (Bennett, 2002), have been described in a substantial number of brain areas, including the cerebral cortex (Peters, 1980), hippocampus (MacVicar and Dudek, 1981), olfactory bulb (Landis et al., 1974), cerebellar cortex (Sotelo and Llinás, 1972), spinal cord (Matsumoto et al., 1988), trigeminal nucleus (Hinrichsen and Larramendi, 1968), and inferior olive (Sotelo et al., 1974; De Zeeuw et al., 1989). Most, if not all, of the neuronal gap junctions in these brain regions are formed by connexin 36 (Cx36), a gap

Received Jan. 31, 2003; revised Mar. 17, 2003; accepted Mar. 26, 2003.

This work was supported by grants from Nederlandse Organizate von Wetenchappelyk Ondersonk (NWO)Medische Wetenschappen (MW) and NWO-Algemene Levens Wetenschappen (ALW), Human Frontier Science Program (C.I.D.), European Economic Community (C.I.D., Y.Y.), the Israel Science Foundation (Y.Y.), the German Research Association (SFB 400, E3 and Wi 270/22-3), and the Fonds der Chemischen Industrie (K.W.). We thank E. Dalm, M. Rutteman, and E. Haasdijk for excellent technical assistance.

Correspondence should be addressed to Dr. C. I. De Zeeuw, Department of Neuroscience, Medical Faculty, Erasmus MC, 3000DR Rotterdam, The Netherlands. E-mail: c.dezeeuw@erasmusmc.nl.

Copyright $\odot 2003$ Society for Neuroscience $\quad$ 0270-6474/03/234700-12\$15.00/0 junction protein specific for neurons (Condorelli et al., 1998; Rash et al., 2000). The functions of Cx36 in the hippocampus and cerebral cortex were addressed recently in a series of knock-out studies. It was suggested that axo-axonal gap junctions are crucial for high-frequency ripple oscillations in CA1 pyramidal cells (Schmitz et al., 2001; Spruston, 2001; Maier et al., 2002), whereas gap junctions between interneurons in the cerebral cortex may be necessary for the generation of synchronous inhibitory activities underlying gamma oscillations (Deans et al., 2001; Hormuzdi et al., 2001). In addition, it has been shown that visual transmission is probably delayed in Cx36-deficient mice because of impaired coupling between amacrine and bipolar cells in the retina (Gueldenagel et al., 2001). Despite these evidences, the correlation between the absence of $\mathrm{C} \times 36$ and neuronal gap junctions remains to be demonstrated at the ultrastructural level. This issue is particularly relevant because compensatory mechanisms such as an upregulation of other connexins or secondary morphological or cell physiological reactions could occur.

The high levels of $\mathrm{Cx} 36$ found in the rat inferior olive suggest 
that electrotonic coupling is most prominent in this brain region (Condorelli et al., 1998; Belluardo et al., 2000). This notion is also supported by the high density and distribution of dendritic lamellar bodies, which are associated with dendrodendritic gap junctions (De Zeeuw et al., 1995, 1997). Several roles have been proposed for electrotonic coupling in the inferior olive. For example, clustering of coupled olivary cells could play a role during development in the formation of sagittally organized zones in the cerebellar cortex, each of which receives its climbing fiber input from a particular olivary subnucleus (Voogd and Bigaré, 1980; De Zeeuw et al., 1994). Other reports propose that electrotonic coupling in the olivary neurons may underly their ability to fire synchronously and thereby to trigger the onset of movements (Welsh et al., 1995; Ivry, 1996; Lang, 2001), or they raise the possibility that this process may, in fact, contribute to cerebellar motor learning (De Zeeuw et al., 1998; Kistler et al., 2000). Furthermore, several studies have provided evidence that electrical coupling is essential for the generation of subthreshold oscillations in the inferior olive (Llinás and Yarom, 1981a,b, 1986; Lampl and Yarom, 1993, 1997; Manor et al., 1997, 2000; Loewenstein et al., 2001), which in turn could serve as a generator of temporal patterns (Yarom and Cohen, 2002).

However, a recent study of $\mathrm{Cx} 36$-deficient mice showed that their olivary neurons display subthreshold rhythmic activities, despite the fact that they lack functional coupling (Long et al., 2002). Moreover, these mutants show a normal motor behavior, in that their locomotion and compensatory eye movements are relatively unaffected and they show a synchronized tremor after harmaline injections, which is comparable with that in wild-type mutants (Kistler et al., 2002). These findings raise the question of how the rhythmic subthreshold activities in olivary neurons can be sustained in the Cx36 knock-out mutants and whether gap junctions are, in fact, essential for the generation of subthreshold rhythmic activities in wild-type mutants. After all, if there are no secondary compensations in the mutants, one could argue indeed that gap junctions between olivary neurons are not essential for the oscillations in wild types (Long et al., 2002).

Here, we demonstrate that a lack of $\mathrm{Cx} 36$ in the inferior olive leads to abnormally thick dendrites with nonfunctional gapjunction-like structures, which in turn results in altered membrane properties that can account for the ability of olivary neurons to produce oscillatory behavior in the absence of normal gap junctions. We propose that the adaptive changes in intrinsic properties in the noncoupled network, such as to enable rhythmic activity, emphasize the importance of these oscillations for the normal function of the olivocerebellar system.

\section{Materials and Methods}

In situ hybridization. Cx36-deficient and wild-type mice were generated and characterized as described by Gueldenagel et al. (2001). Subsequently, they were anesthetized by asphyxiation in $\mathrm{CO}_{2}$ and decapitated, and their brains were carefully removed, frozen on dry ice, and stored at $-80^{\circ} \mathrm{C}$. The brainstems containing the inferior olive were cut into $14 \mu \mathrm{m}$ sections on a cryostat, mounted on polylysine-coated glass slides, and stored at $-80^{\circ} \mathrm{C}$. Slides were fixed in $4 \%$ paraformaldehyde $(5 \mathrm{~min}$ ) and acetylated in $1.4 \%$ triethanolamine and $0.25 \%$ acetic anhydride. Sections were then prehybridized ( $1 \mathrm{hr}$ ) in buffer containing $50 \%$ formamide, $5 \times$ SSC, $5 \times$ Denhardt's solution, $250 \mu \mathrm{g} / \mathrm{ml}$ yeast tRNA (Sigma, St. Louis, MO) and $500 \mu \mathrm{g} / \mathrm{ml}$ acid-alkali cleaved salmon testis DNA (Sigma). Hybridization was performed overnight at $65^{\circ} \mathrm{C}$ in prehybridization buffer containing $100 \mathrm{ng} / \mathrm{ml}$ digoxigenin-UTP-labeled cRNA probes. Probes were generated using a digoxigenin RNA labeling kit (Roche) according to the manufacturer's instructions. Sense and antisense probes generated against the full-length coding sequence of $\mathrm{Cx} 36$ were then hydrolyzed in $40 \mathrm{~mm} \mathrm{NaHCO}$ and 60 $\mathrm{mm} \mathrm{Na} \mathrm{CO}_{3}$ for $25 \mathrm{~min}$ at $60^{\circ} \mathrm{C}$ to generate fragments of $\sim 300$ bases. After hybridization, sections were washed in $0.2 \times \mathrm{SSC}$ at $65^{\circ} \mathrm{C}$ and blocked in 0.1 M Tris, pH 7.5, $0.15 \mathrm{M} \mathrm{NaCl}$, and $10 \%$ heat-inactivated sheep serum (Sigma) for $1 \mathrm{hr}$ at room temperature. Alkaline phosphatase-conjugated antidigoxigenin antibodies (Roche) were added to the sections in a dilution of 1:5000 in $0.1 \mathrm{~m}$ Tris, pH 7.5, $0.15 \mathrm{M} \mathrm{NaCl}$, and $1 \%$ heat-inactivated sheep serum and incubated overnight at $4^{\circ} \mathrm{C}$. After washing of the sections, color reactions were performed in $0.1 \mathrm{M}$ Tris, $\mathrm{pH}$ 9.5, $0.1 \mathrm{M} \mathrm{NaCl}$, $50 \mathrm{mM} \mathrm{MgCl}_{2}$, 2 mu levamisole (Sigma), $0.35 \mathrm{mg} / \mathrm{ml}$ nitroblue tetrazolium (Roche), and 0.18 $\mathrm{mg} / \mathrm{ml}$ 5-bromo-4-chloro-3-indolylphosphate (Roche). Reactions were terminated on visual inspection $(\sim 18 \mathrm{hr})$, counterstained in $0.1 \%$ Fast Red, dehydrated, and mounted in Permount (Fisher Scientific, Houston, TX).

Immunocytochemistry. Cx36-deficient and wild-type mice were anesthetized by asphyxiation in $\mathrm{CO}_{2}$ and decapitated. Brains were dissected cut into frontal brain blocks, and frozen in $8 \%$ methylcyclohexan in 2 -methylbutan $\left(\mathrm{v} / \mathrm{v},-80^{\circ} \mathrm{C}\right)$. Immunohistochemistry was performed on cryosections of $14 \mu \mathrm{m}$ thickness fixed in cold ethanol for $10 \mathrm{~min}$ at $-20^{\circ} \mathrm{C}$, rinsed in PBS, and preincubated in blocking buffer $(10 \%$ normal goat serum and $0.1 \%$ Triton X-100 in PBS) for $30 \mathrm{~min}$. The Cx36 antibody was diluted in blocking buffer (dilution 1:500), and sections were incubated overnight at room temperature. This affinity-purified polyclonal antibody was directed to the cytoplasmic loop of mouse Cx36 and has been described by Teubner et al. (2000). Preimmuneserum to this antibody served as an additional control for the specificity of the immunoreaction. After incubation, samples were rinsed in PBS, followed by a 30 min incubation in $0.2 \%$ BSA in PBS. Incubation with the secondary antibody (Alexa Fluor 488 goat anti-rabbit; Molecular Probes, Leiden, The Netherlands) was performed at a 1:4000 dilution in blocking buffer for $2 \mathrm{hr}$ at room temperature. After rinsing in PBS, the sections were mounted using the ProLong Antifade kit (Molecular Probes). Fluorescence was documented using confocal imaging microscopy (LSM 510 inverted confocal microscope, argon/krypton laser; Zeiss Oberkochen, Germany). Data were collected as single planes using the single track scanning module. All data were exported as TIFF files into Adobe Photoshop 5.5 (Adobe Imaging Systems Inc., San Jose, CA) for documentation.

Rapid Golgi staining. Cx36-deficient and wild-type mice were anesthetized by asphyxiation in $\mathrm{CO}_{2}$, perfused with $0.01 \mathrm{M}$ sodium cacodylate in $9 \% \mathrm{NaCl}$ and $4 \%$ paraformaldehyde in 0.1 sodium cacodylate, and decapitated. Brainstems including the inferior olive were dissected, cut into $80 \mu \mathrm{m}$ slices, and incubated for $2 \mathrm{~d}$ in $3.5 \% \mathrm{~K}_{2} \mathrm{Cr}_{2} \mathrm{O}_{7} / 0.12 \% \mathrm{OsO}_{4}$. Subsequently, the sections were rinsed in $3.5 \% \mathrm{~K}_{2} \mathrm{Cr}_{2} \mathrm{O}_{7}$, embedded in $4 \%$ agar, and rinsed in $0.75 \% \mathrm{AgNO}_{3}$ and Aquadest at $4^{\circ} \mathrm{C}$. After $60 \mathrm{~min}$ in kodalith, the sections were rinsed in Aquadest at $4^{\circ} \mathrm{C}, 1 \% \mathrm{Na}_{2} \mathrm{~S}_{2} \mathrm{O}_{3}$, and $5 \% \mathrm{H}_{2} \mathrm{O}$, and mounted. Quantitative analyses of the Golgi material were performed with the use of automized camera lucida equipment. Quantitative analyses were done with the use of camera lucida equipment.

Electron microscopy. Adult Cx36-/- mice, Cx36+/- mice, and wildtype littermates were anesthetized with an overdose of Nembutal and transcardially perfused with $4 \%$ paraformaldehyde and $1 \%$ glutaraldehyde in $0.12 \mathrm{~m}$ cacodylate buffer; the brainstem containing the inferior olive was then processed for electron microscopy as described by De Zeeuw et al. (1989). In short, 100- $\mu \mathrm{m}$-thick sections were cut on a vibratome, osmicated in $\mathrm{OsO}_{4}$, stained en bloc in tannic acid and uranyl acetate, dehydrated in dimethoxypropane, and embedded in Araldite. Subsequently, the various olivary subnuclei were identified on semithin sections, pyramids were made, and ultrathin sections were cut accordingly on a Reichert ultratome, counterstained with uranyl acetate and lead citrate, and examined with the use of a Philips CM-100 electron microscope. The sections of the various tissue blocks were systematically screened per surface area, and the gap junctions and gap-junction-like structures were identified and quantified.

Dye coupling. The experiments were performed on $300 \mu \mathrm{m}$ coronal slices of the inferior olive obtained from the brainstem of adult wild-type and homozygous Cx36 null-mutant mice. After identification of an olivary neuron, glass micropipettes containing either Lucifer yellow (2$4 \%$ ) or Neurobiotin (5\%) were inserted into the cell according to Bacskai and Matesz (2002). In the Lucifer yellow experiments, frozen sections were examined under a fluorescent microscope, whereas Neurobiotin 


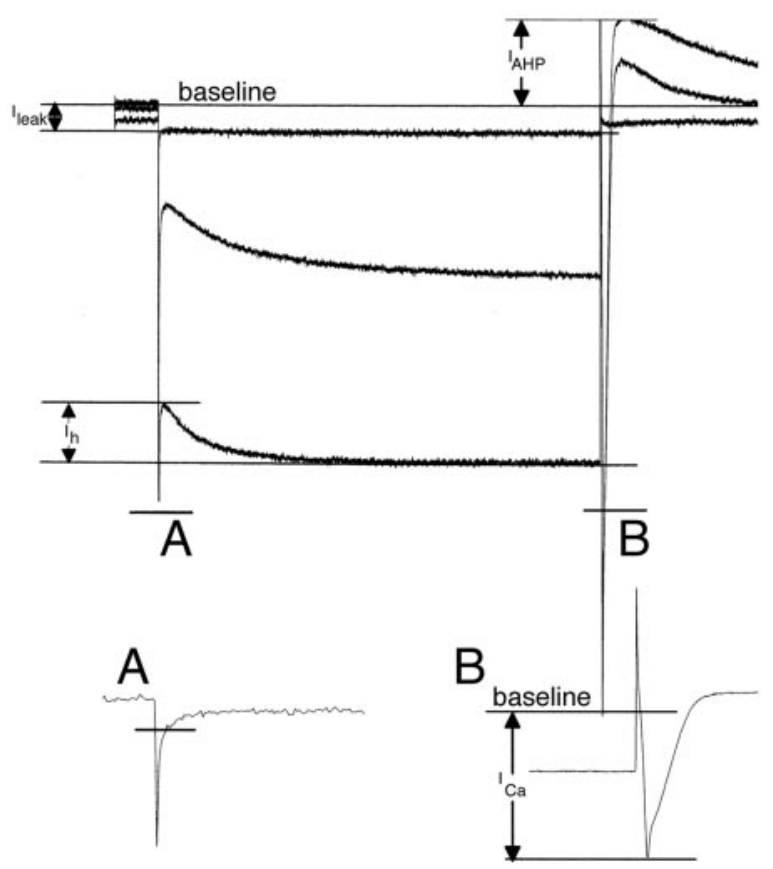

Figure 1. Characterizing ionic currents. Negative voltage steps from a holding potential of $-50 \mathrm{mV}$ were used to characterize the ionic currents. Three examples of current responses to voltage steps of $-4,-28$, and $-56 \mathrm{mV}$ are shown. The input resistance $\left(R_{\text {in }}\right)$ was measured from the amplitude of the current response to a $-4 \mathrm{mV}$ voltage step as shown on the trace $\left(I_{\text {leak }}\right)$. The afterhyperpolarizing current $\left(I_{\text {AHP }}\right)$ was measured from the baseline to the peak of the outward current at the end of the voltage step. The $I_{A H P}$ current is a mixture of $h$ current and possibly $\mathrm{Ca}^{2+}$-dependent $\mathrm{K}^{+}$current. The $I_{\mathrm{h}}$ was measured as the difference between the initial current and the steady-state current developed at the end of the hyperpolarizing voltage step. The capacitance was calculated from the integral of the capacitive current induced by a $-4 \mathrm{mV}$ voltage step (inset A). The area to integrate was limited to the fast transient only (horizontal bar). As expected, this definition resulted in a linear relationship between the input conductance and the cell capacitance, as demonstrated in Figure 2. The calcium current is enlarged in inset $B$, and the amplitude is measured as shown.

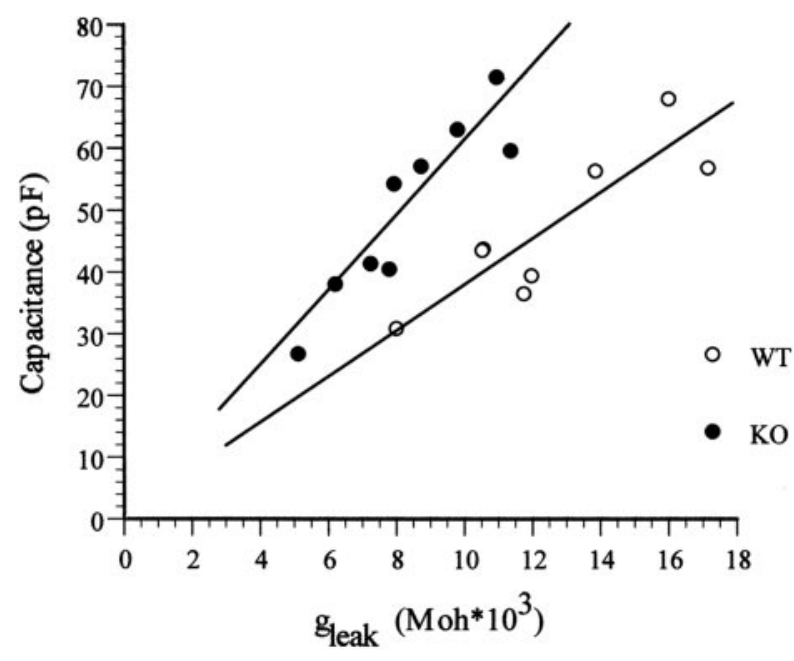

Figure 2. The measured input resistance $\left(R_{\text {in }}\right)$ is correlated with the calculated capacitance. $1 / R_{\text {in }}$ is linearly related to the capacitance $\left(R^{2}=0.76\right.$ for wild type and $R^{2}=0.85$ for knockout). The slope of the linear feet gives us the average time constant of these cells $(\tau=3.7 \mathrm{msec}$ for wild type and $\tau=6.03$ msec for knock-out). WT, Wild type; K0, knock-out.

was visualized with the use of $\mathrm{ABC}$ reagent and $\mathrm{AAB}$ solution according to standard procedures.

Electrophysiology. Whole-cell patch technique was used for intracellular recordings of either voltage or current activity of olivary neurons in
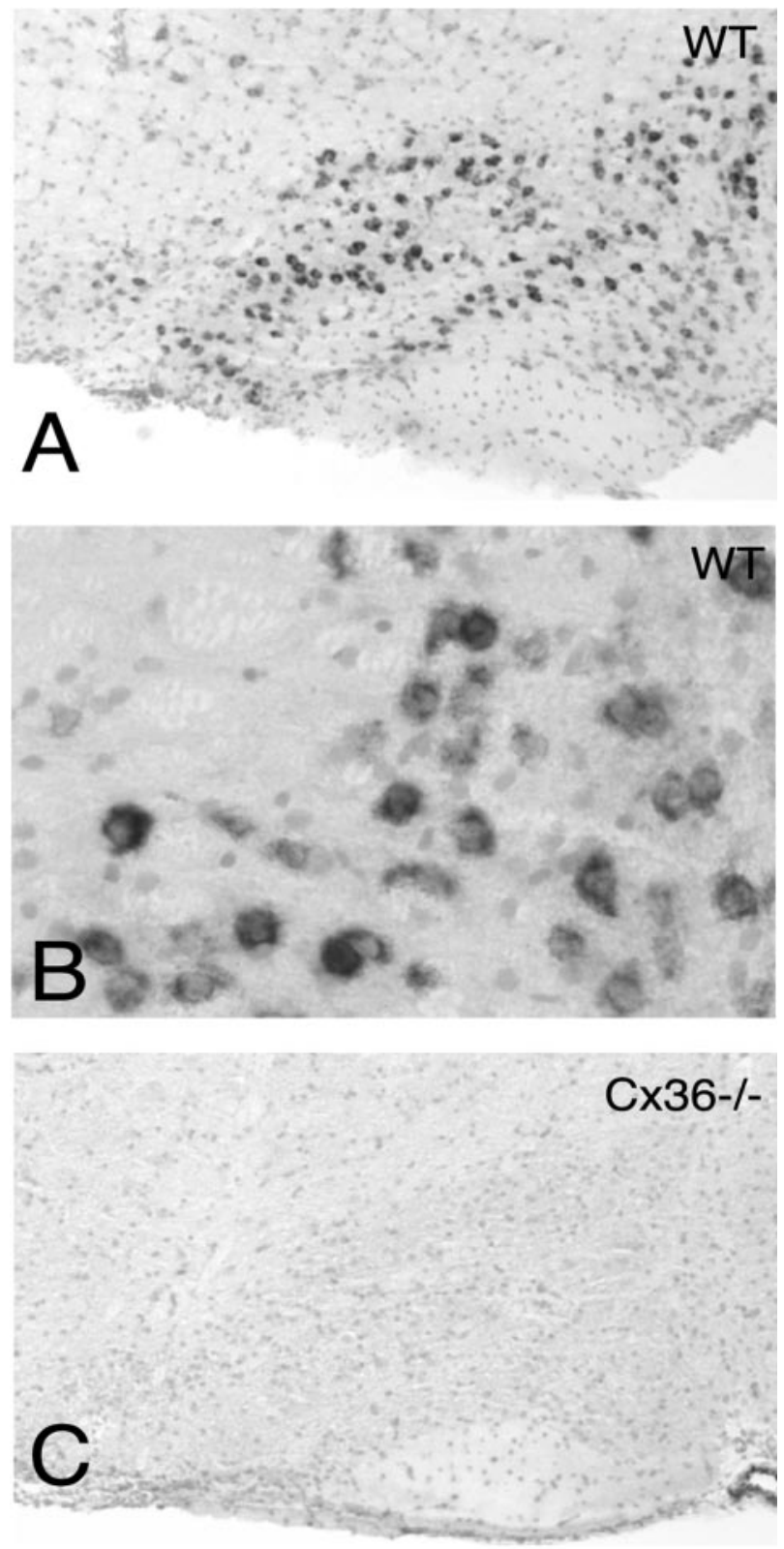

Figure 3. Ubiquitous distribution of $\mathrm{C} \times 36 \mathrm{mRNA}$ in the inferior olive of the mouse. $A$, Low magnification of labeled olivary neurons in medial accessory olive, dorsal accessory olive, and principal olive after in situ hybridization; with the use of $\mathrm{C} 36$ antisense probes, all neurons of all olivary subnuclei of wild-type (WT) mice were positively labeled. B, High magnification of labeled neurons in the medial accessory olive. $C$, In contrast, none of the olivary neurons in $C \times 36$ knock-out mice were labeled with the use of antisense probes. Scale bars: $A, 100 \mu \mathrm{m} ; B, 20 \mu \mathrm{m}$; C, $120 \mu \mathrm{m}$.

brainstem slices. Parasagittal slices $(300 \mu \mathrm{m})$ were prepared from the brainstem of wild-type and homozygous Cx36 null-mutant mice that were at least 1 month of age. Slice preparation and recording techniques have been described in detail previously by Devor and Yarom (2002a,b). Recordings were performed at room temperature $\left(22-25^{\circ} \mathrm{C}\right)$ in a physiological solution containing (in $\mathrm{mm}$ ): $127.2 \mathrm{NaCl}, 1.8 \mathrm{KCl}, 1.3 \mathrm{MgSO}_{4}$, $1.2 \mathrm{KH}_{2} \mathrm{PO}_{4}, 26 \mathrm{NaHCO}_{3}, 10$ glucose, and $2.4 \mathrm{CaCl}_{2}$. The pipette solution contained (in $\mathrm{mm}$ ): $4 \mathrm{NaCl}, 10^{-3} \mathrm{CaCl}_{2}, 140 \mathrm{~K}$-gluconate, $10^{-2}$ EGTA, $4 \mathrm{Mg}$-ATP, and 10 HEPES, pH 7.2. In the voltage-clamp experiments, $1 \mu \mathrm{M}$ TTX was added to the physiological solution.

To characterize the densities of ionic currents, we measured the cur- 

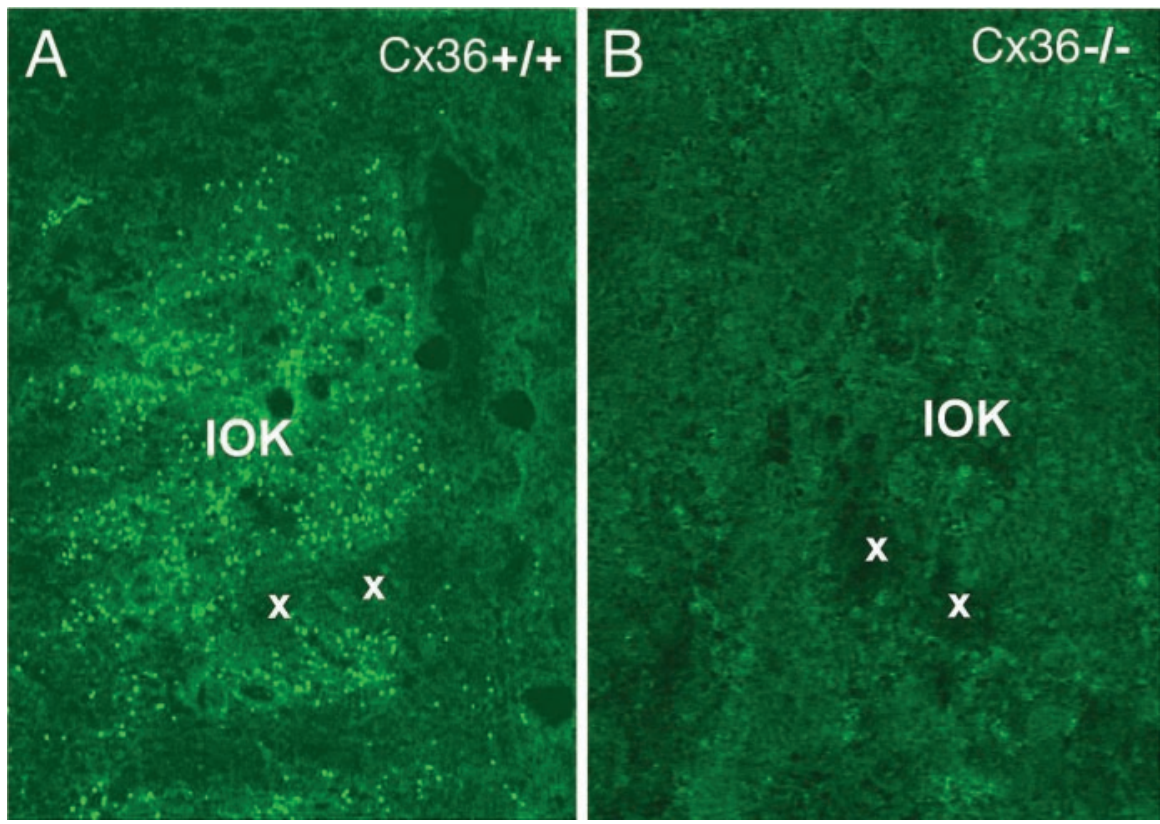

Figure 4. Punctate labeling in olivary neuropil after immunocytochemistry with the use of anti-Cx36. A, In wild-type mice, the entire neuropil was filled with labeled puncta; this micrograph shows an example of labeling in the smallest olivary subnucleus, the dorsal cap of Kooij (IOK). B, In the Cx36-deficient mouse, no puncta were visible. x, Examples of cell bodies.
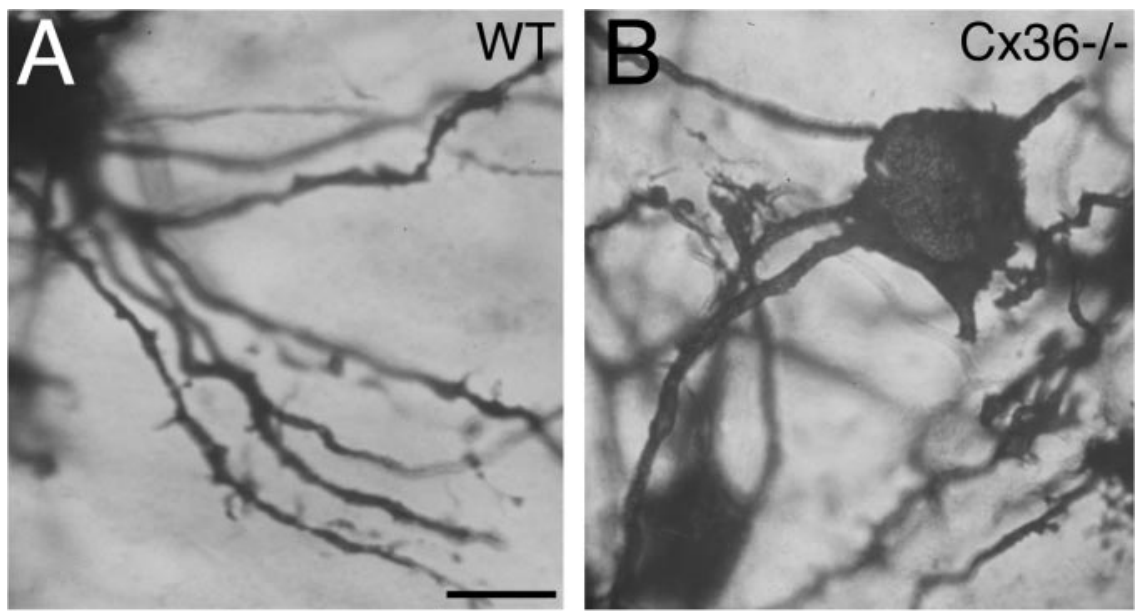

Figure 5. Rapid Golgi staining of olivary neurons in wild-type (WT) mice $(A)$ and $\mathrm{x} \times 36-/-$ mice $(B)$. Note that the proximal dendrites of $\mathrm{C} \times 36-1-$ mice are thicker than those of the wild-type mice. The magnifications of $A$ and $B$ are the same. Scale bar, $9.7 \mu \mathrm{m}$.

rent responses to a series of negative voltage steps from a holding potential of $-50 \mathrm{mV}$. The current traces (Fig. $1 \mathrm{~A}$ ) were averaged and saved for off-line analysis. The capacitive current (used for estimating the surface area; inset $A$ ) and the input resistance were measured from the response to $-4 \mathrm{mV}$ voltage step (top trace). The $h$ current and the $\mathrm{Ca}^{2+}$ current (inset $B$ ) as well as the late outward current $\left(I_{\mathrm{AHP}}\right)$ were measured as indicated in the figure. Because the capacitive current is correlated with surface area, we used this current to compute current densities. It is therefore of utmost importance to measure the capacitive current with maximal reliability. To demonstrate the validity of our measurement method, we plotted the cell capacitance (calculated from the integral of the capacitive current) as a function of the input conductance (Fig. 2). The linear relationships for both wild type and knock-out assessed the validity of our measurement protocol. The slopes of these linear curves closely represent the membrane time constants (3.7 and $6.0 \mathrm{msec}$ for wild type and knock-out, respectively).

Dynamic clamp. We used the dynamic-clamp technique (Sharp et al.,
1993) to artificially decrease a leak conductance, or add an low-threshold calcium (LTC)-like conductance, into olivary neurons. Briefly, we continuously acquired the voltage of the cell $(V)$, computed a conductance, calculated the driving force, and injected the product back into the cell, using an update rate of $2 \mathrm{kHz}$. To decrease a leak conductance $g_{\mathrm{L}}$, before the dynamic-clamp injection, we measured the resting potential of the cell $\left(V_{\mathrm{r}}\right)$ and used this value as the equilibrium potential for this conductance. To add an LTC-like conductance, $g_{\mathrm{T}}$, we solved on-line a set of differential equations that described the voltage dependence and time dependence of this conductance. We used the following equation: $g_{\mathrm{T}}=G_{\mathrm{T}} m h$, where $G_{\mathrm{T}}$ is the maximal conductance and $x=m$, $h$ are state variables that obey the following kinetics: $d x / d t=(x \infty(V)-x) / \tau_{x}$, where $x \infty(V)$ is a steady-state curve of the form $\left(1+\exp ^{(V-V 1 / 2) /}\right.$ $\left.{ }^{-1}\right)^{-1} V_{1 / 2}$ in $\mathrm{mV}: m=-61, h=-85.5 ; k$ in $\mathrm{mV}$ : $m=4.3, h=8.6 ; \tau_{m}=5 \mathrm{msec}$; and $\tau_{\mathrm{h}}$ is voltage dependent equal to $220 \mathrm{msec}$ at $-90 \mathrm{mV}$ (for details, see Manor et al., 1997).

\section{Results \\ In situ hybridization and immunocytochemistry}

To find out whether Cx36 is ubiquitously expressed among neurons of the olivary subnuclei in mice, we investigated the murine inferior olive using in situ hybridization and immunocytochemistry. After application of antisense Cx36 probes, all neurons of all olivary subnuclei of wildtype mice were positively labeled at all rostrocaudal levels (Fig. 3). In contrast, none of the olivary neurons in wild-type mice were labeled with the use of sense probes, and none of the olivary neurons in Cx36 knock-out mice were labeled with the use of antisense probes. After immunocytochemical application of antibodies against Cx36, all olivary subnuclei of wild-type mice showed a clear punctate labeling throughout their neuropil, whereas no labeling was observed in Cx36 null-mutant mice (Fig. 4). Together, these data indicate that all olivary neurons in wild-type mice express $\mathrm{Cx} 36$ and form gap junctions.

\section{Cytoarchitecture}

Analyses of Golgi-stained sections of the inferior olive of wild-type mice $(n=4)$ and Cx36 knock-out mice $(n=4)$ did not reveal a significant difference in average diameter of the cell bodies (12.8 \pm $1.4 \mu \mathrm{m}$ for wild-type mice vs $13.7 \pm 0.9 \mu \mathrm{m}$ for Cx36 knock-out mice), average length of the stained dendrites ( $59 \pm 23$ vs $60 \pm 25$ $\mu \mathrm{m})$, or average density of stained spines per micrometer of dendrite $(0.13 \pm 0.05$ vs $0.12 \pm 0.04)$. However, we did observe a significant difference in the average thickness of the proximal dendrites (Fig. 5). When measured $5 \mu \mathrm{m}$ distally to the soma, the average diameter of the dendrites was $1.9 \pm 0.3 \mu \mathrm{m}$ in wild types and $2.6 \pm 0.3 \mu \mathrm{m}$ in Cx36 knock-outs ( $p<0.05 ; t$ test). The ramifications of the dendrites, in contrast, were not different when analyzed with topological analyses that provided values for the symmetry of arborizations (Van Pelt et al., 1992). 

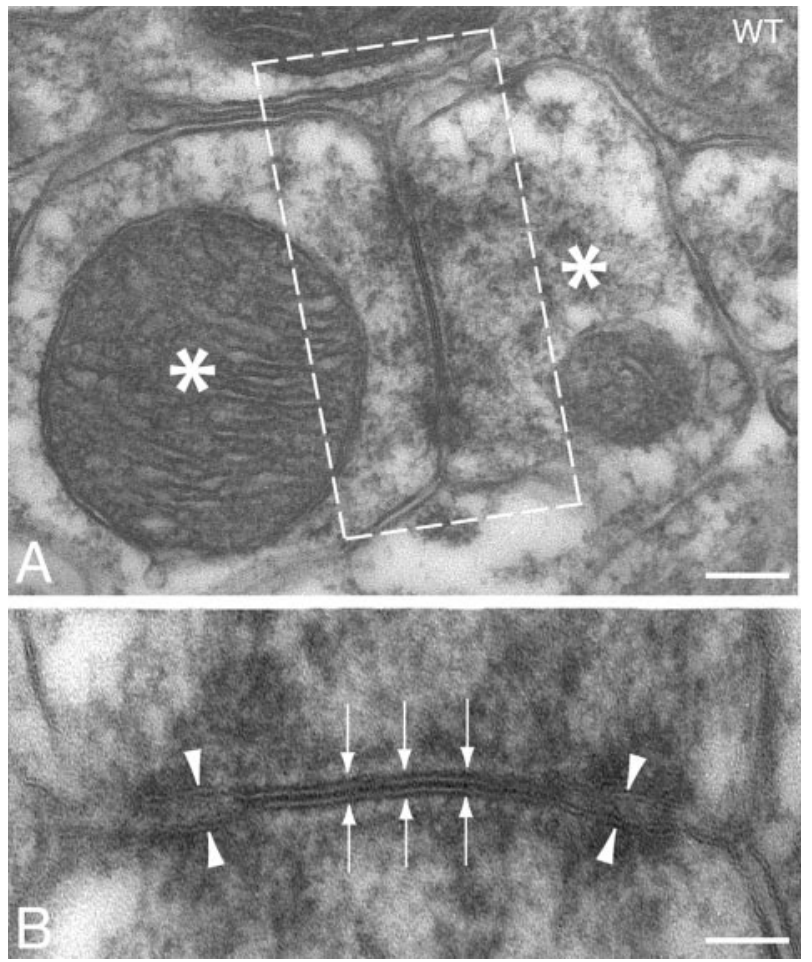

Figure 6. Ultrastructural characteristics of a dendrodendritic gap junction in the inferior olive of a wild-type (WT) mouse. In wild-type mice, the gap junctions between olivary dendritic spines (asterisks) showed electron-dense deposits in the cytoplasm at both sides of the membrane; in addition, they had attachment plaques (arrowheads) surrounding the plaque with gap-junction channels (arrows), and the interneuronal gap of this plaque was $\sim 3 \mathrm{~nm}$ thick. $B$ shows a higher magnification of the inset depicted in $A$. Scale bars: $A, 167 \mathrm{~nm} ; B, 82 \mathrm{~nm}$.

\section{Electron microscopy}

Ultrastructural analyses of gap junctions $(n=178)$ of neurons in the inferior olive of wild-type mice $(n=6)$ showed that they have the same general morphological characteristics as described for other mammals (for review, see De Zeeuw et al., 1998). Characteristics consist of a plaque with an average diameter of $272 \pm 26$ $\mathrm{nm}$ and an interneuronal space of $3.2 \pm 0.4 \mathrm{~nm}$ thickness; they show electron-dense deposits at both sides of the membrane and have attachment plaques surrounding the plaque with gapjunction channels (Fig. 6). Moreover, the vast majority of olivary gap junctions in mice connect two dendritic spines that are located in the core of a glomerulus, which is surrounded by both inhibitory and excitatory terminals.

In all olivary subnuclei of homozygous Cx36-deficient mice ( $n=5)$, we observed gap-junction-like structures $(n=144)$ that met all criteria mentioned previously, except that they lacked a plaque with a narrow interneuronal space; their average interneuronal space was approximately three times wider $(9.2 \pm 1.4$ $\mathrm{nm} ; p<0.004$; Student's $t$ test) (Figs. 7, 8). The average distance between the attachment plaques $(423 \pm 92 \mathrm{~nm})$ of the gapjunction-like structures was not significantly different ( $p=0.64$; $F$ test) from that of gap junctions in wild-type littermates (416 \pm $46 \mathrm{~nm}$ ). All gap-junction-like structures were also positioned between two dendritic profiles in the core of glomeruli. Moreover, the morphological characteristics of the glomeruli themselves, just as those of the extraglomerular neuropil, including the presence and shape of dendritic lamellar bodies, appeared normal. However, the average density of gap-junction-like structures in the olive of Cx36-deficient mice $\left(56\right.$ per $\mathrm{mm}^{2}$ ) was significantly lower ( $p<0.01$; Student's $t$ test) than that of gap junctions in wild-type littermates $\left(85\right.$ per $\left.\mathrm{mm}^{2}\right)$. Smaller-sized gap-junction plaques, as described by Raviola and Gilula (1975) for example, were not observed in the mutants. With regard to the size of the dendrites, we observed that the average diameter of proximal dendrites $(2.7 \pm 0.4 \mu \mathrm{m})$, as identified by the presence of ribosomes (De Zeeuw et al., 1989), was significantly larger $(p<0.03$; $t$ test) in mutants than in wild types $(1.8 \pm 0.4 \mu \mathrm{m})$. No significant differences were observed for the diameters of distal dendrites. The morphology and density of glial gap junctions were not affected in Cx36-deficient mice. Finally, the density of neurons as counted in both the ultrathin and semithin sections was not significantly different in Cx36-deficient mice.

In the inferior olive of heterozygous Cx36-deficient mice $(n=$ $4)$, we observed gap junctions $(n=73)$ that showed all essential criteria for true gap junctions, including a normal interneuronal space of $\sim 2.9 \pm 0.3 \mathrm{~nm}$. Yet, the average diameter of the plaque was significantly reduced to $209 \pm 27 \mathrm{~nm}$ compared with wildtype mice ( $p<0.05$; Student's $t$ test) (Figs. 7,8$)$. Even so, the average distance between the attachment plaques bordering the gap-junction plaque as analyzed in the two-dimensional electron microscopic plane $(454 \pm 77 \mathrm{~nm})$ was similar to those in wild types $(416 \pm 46 \mathrm{~nm})$ and homozygous $(423 \pm 92 \mathrm{~nm})$ animals, and the density of gap junctions $\left(78\right.$ per $\left.\mathrm{mm}^{2}\right)$ was not significantly lower than that of wild-type animals.

We conclude from these data that (1) the absence of $\mathrm{Cx} 36$ leads to plaque-lacking gap-junction-like structures with an abnormally wide interneuronal space, (2) reduced expression of this connexin results in gap junctions with smaller plaques, and (3) Cx36 is therefore probably necessary for the formation and assembly of connexin-hemichannels in plaques of neuronal gap junctions in the inferior olive. Thus, if there is any morphological compensation in the homozygous knock-out mice, it appears to occur at the level of proximal dendrites rather than at the abnormally noncoupled dendritic spines.

\section{Dye coupling}

The ultrastructural data described above suggest that there is no functional coupling in the inferior olive of $\mathrm{Cx} 36$-deficient mice. To confirm this observation, we injected Lucifer yellow into olivary neurons in 250- $\mu \mathrm{m}$-thick slices of both wild-type and Cx36deficient mice (Fig. 9). In slices of wild-type animals $(n=21)$, the intracellular injections provided labeled clusters of 4-14 neurons (with an average of $9 \pm 3.2$ ). In contrast, virtually all injections in mutant slices yielded single labeled neurons $(n=16)$, with the exception of two cases in which we obtained a cluster of two and three cells. Apart from the differences in the size of the proximal dendrites, we did not observe any sign of abnormal morphology or collateralization of the olivary axons or dendrites. In addition, we investigated the coupling with the use of intracellular injections of Neurobiotin in Cx36-deficient mice $(n=8)$ and wildtype littermates $(n=6)$; in all Cx36-deficient mice, the injections resulted in labeling of single neurons only $(n=16)$, whereas those in the wild types always provided clusters of multiple neurons $(n=18$, with an average of $8 \pm 3.8)$. These results indicate that electrotonic coupling in the inferior olive is severely affected in Cx36-deficient mice.

\section{Electroresponsive properties}

To investigate the impact of a lack of $\mathrm{Cx} 36$ on electroresponsive properties of olivary neurons, whole-cell patch recordings were performed in wild-type mice $(n=43)$ and homozygous Cx36deficient mice $(n=22)$. In dual recordings from wild-type olivary neurons, $62 \%(n=8)$ of the pairs showed bidirectional 


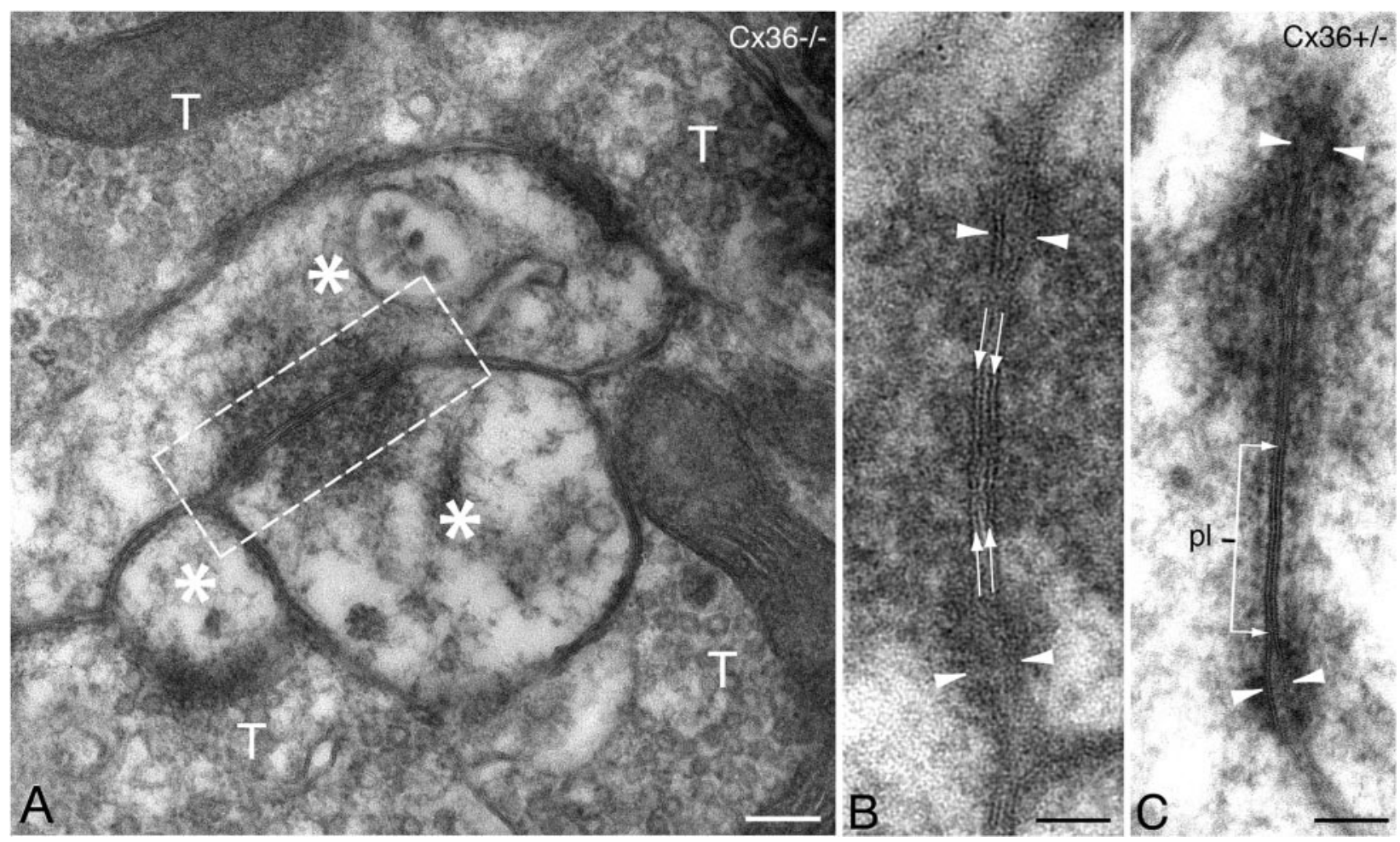

Figure 7. Ultrastructural characteristics of a dendrodendritic gap-junction-like structure in the inferior olive of a $(x 36$-deficient mouse $(A, B)$ and a $(x 36+/-$ mouse ( $C$ ). In homozygous Cx36-deficient mice, no normal gap junctions were observed, but instead the dendrites showed numerous gap-junction-like structures with a widened interneuronal gap of $\sim 9 \mathrm{~nm}$ (arrows in $B$ ). Note that the micrograph in $A$ shows a typical olivary glomerulus with a core of dendritic spines (asterisks) surrounded by terminals ( $\mathrm{T}$ ) and glia. In heterozygous $\mathrm{Cx36-deficient} \mathrm{mice,} \mathrm{the} \mathrm{olivary} \mathrm{gap}$ junctions showed a normal interneuronal gap of $\sim 3 \mathrm{~nm}$, but the average diameter of the plaque ( $\mathrm{pl}$ in $C$ ) was significantly reduced, whereas the distance between the attachment plaques (arrowheads) remained normal. $B$ shows a higher magnification of the inset depicted in $A$. Scale bars: $A, 150 \mathrm{~nm} ; B, 75 \mathrm{~nm} ; C, 105 \mathrm{~nm}$.

direct current flow (Fig. $10 \mathrm{~A}$ ). None of the 10 pairs of knock-out neurons showed direct coupling (Fig. 10B). These findings support our anatomical findings, which suggest that no functional gap junctions exist in the homozygous mutants. In addition, they illustrate that our $\mathrm{Cx} 36$-deficient mutants, which were created in a different laboratory with a different cloning strategy (Gueldenagel et al., 2001), show the same basic cellular deficits as the line of Cx36 knock-out mice used by Long et al. (2002).

Both wild-type and Cx36-deficient olivary neurons displayed characteristic high- and low-threshold Ca spikes on stimulation with a depolarizing current pulse (Fig. 11, top). As shown previously in rats and guinea pigs (Llinás and Yarom, 1981a,b, 1987; Devor and Yarom, 2002a,b), the low-threshold Ca spike, which triggered an $\mathrm{Na}$-dependent action potential, was readily elicited by a positive current pulse when the membrane voltage was held at hyperpolarized levels (less than $-70 \mathrm{mV}$ ). When the membrane potential was held at depolarized levels (more than -45 $\mathrm{mV}$ ), a positive current pulse elicited an $\mathrm{Na}$-dependent action potential that triggered a high-threshold Ca spike. The latter was manifested as a prolongation of the action potential, followed by a long-lasting hyperpolarization.

Although both wild-type and Cx36-deficient neurons showed similarity in their responses to depolarizing current pulses, they differed considerably in their responses to hyperpolarizing current pulses. The responses of wild-type neurons resembled those previously reported in guinea pig and rat olivary neurons (Llinás and Yarom, 1987; Bal and McCormick, 1997; Devor and Yarom, 2000). Specifically, during a prolonged hyperpolarization, the voltage response partially decreased (sag) and a rebound low- threshold response was elicited on termination of the hyperpolarization (Fig. 11, bottom left). The responses of mutant olivary neurons were dramatically different. With a sufficiently large hyperpolarizing pulse, the sag response developed into a lowthreshold Ca spike (Fig. 11, bottom right). An additional increase in the level of hyperpolarization increased the amplitude of the low-threshold Ca spike, eventually triggering an Na-dependent action potential.

\section{Rhythmic activity}

The extraordinary response of all mutant neurons $(n=22)$ to injection of negative current pulses indicates that the lack of $\mathrm{Cx} 36$ leads to abnormal electrical properties of olivary neurons. These properties were manifested as an increase in the neuronal excitability when the membrane potential was more negative than $-60 \mathrm{mV}$. Indeed, when neurons were hyperpolarized by DC injections, rhythmic activity was elicited. Figure 12 (right) shows voltage traces recorded from a mutant neuron at different levels of membrane potential. With no current injected, the neuron was quiescent (top trace). Shifting the membrane potential by $-8 \mathrm{mV}$ evoked rhythmic activity that increased in amplitude and frequency with additional hyperpolarization. Occasionally, the amplitude reached the firing threshold and $\mathrm{Na}$-dependent action potentials were elicited (fourth trace). An average frequency of $2.2 \pm 0.7 \mathrm{~Hz}$ was calculated in seven cells. Additional hyperpolarization blocked this spontaneous rhythmic activity (bottom trace). This behavior considerably differed from the subthreshold oscillatory activity recorded in wild-type neurons, where rhythmic activity was voltage independent and could not be elicited or 

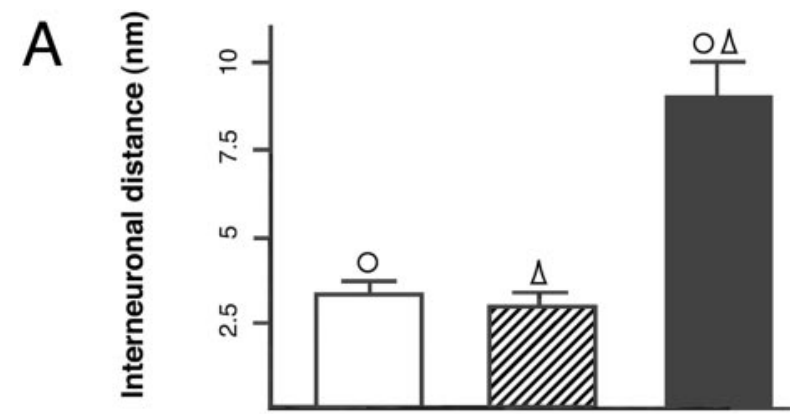

B
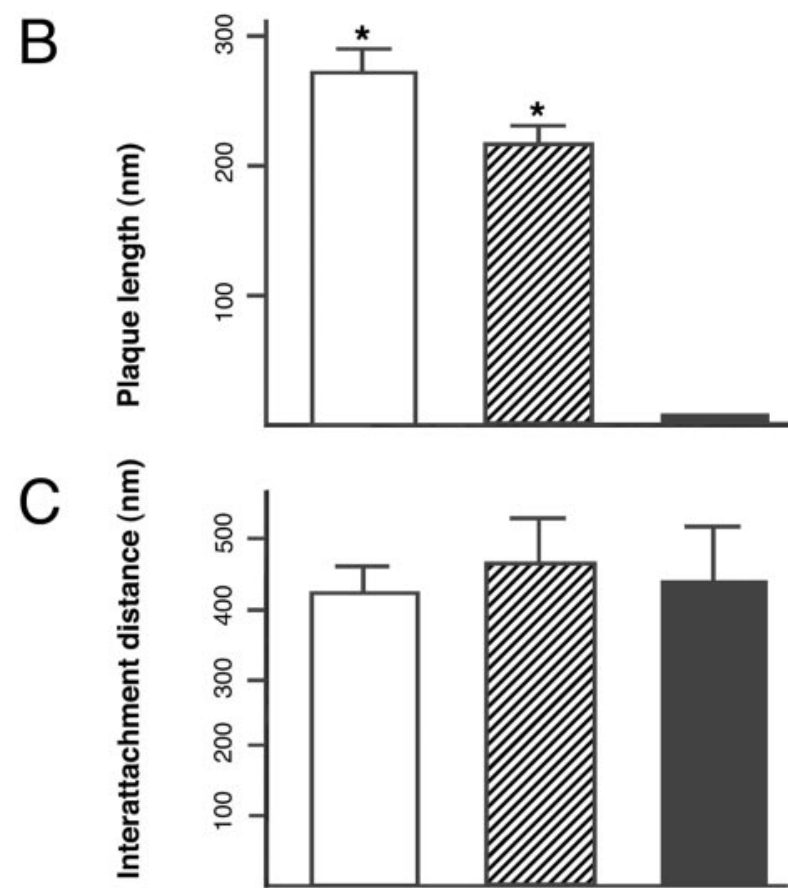

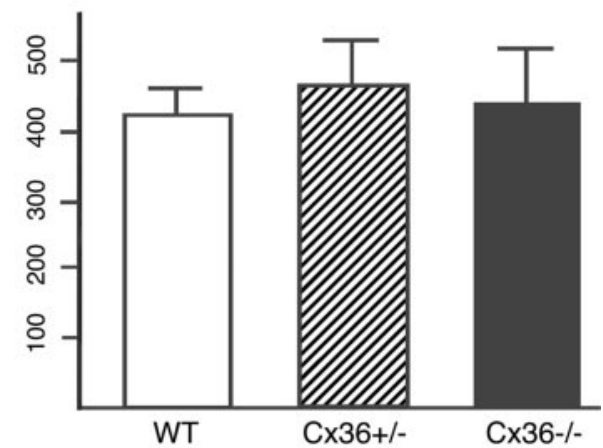

Figure 8. Histograms showing morphometrics of gap junctions and gap-junction-like structures in wild-type (WT), $\mathrm{C} \times 36+1-$, and $\mathrm{C} \times 36-1-$ mutants. $A$, The average interneuronal space of gap-junction-like structures in $\mathrm{C} \times 36-/-$ mutants was significantly smaller than that of gap junctions in wild-type and $C \times 36+1-$ mutants. $B$, The length of the gap-junction plaque in wild-type mutants was significantly longer than that of $\mathrm{C} \times 36+/-$ mutants, whereas it was absent in homozygous (x36-deficient mice. C, In contrast, the distance between the attachment plaques did not differ among the three groups of animals. For visualization of parameters, see Figure 7. Open circles and triangles indicate $p<0.0001$; asterisks indicate $p<0.001$.

abolished by current injection. An example of subthreshold oscillatory activities in a wild-type neuron, which were observed in 14 of 29 cells, is shown in the left panel of Figure 12. Across the different neurons, the average frequency of these oscillations was $1.28 \pm 0.4 \mathrm{~Hz}$. These results show that the subthreshold oscillations in the mutant olivary neurons are generated by the intrinsic properties of the cells, as opposed to the wild-type oscillations that emerge from a network of electrically coupled neurons (Manor et al., 1997; Loewenstein et al., 2001). Hence, the knockout mutation triggers a cascade of events that transforms olivary neurons from quiescent cells to conditional oscillators.

\section{Current measurements}

The finding that olivary neurons seem to transform into conditional oscillators raises the question of what type of changes induce such a functional transformation. In previous modeling studies, we have shown that a model cell consisting of only leak and calcium conductances could be transformed from a quies-
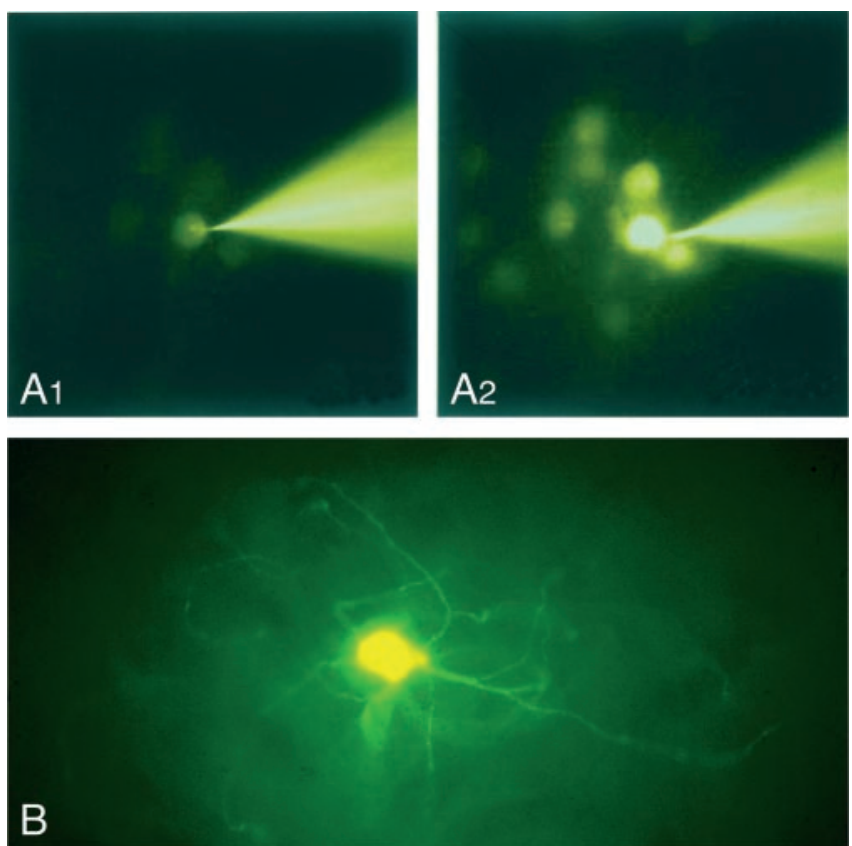

Figure 9. Dye coupling in wild-type mice $(A)$ and homozygous $(x 36$-deficient mice $(B) . A$, In slices of the inferior olive of wild-type animals, intracellular injections with Lucifer yellow provided clusters of approximately nine neurons within a few minutes; the time difference between micrograph of $A_{1}$ and $A_{2}$ is $136 \mathrm{sec}$. $B$, In contrast, injections in slices of Cx36-deficient mice yielded single labeled neurons; note the absence of labeling in neighboring cells despite the visualization of olivary dendrites.
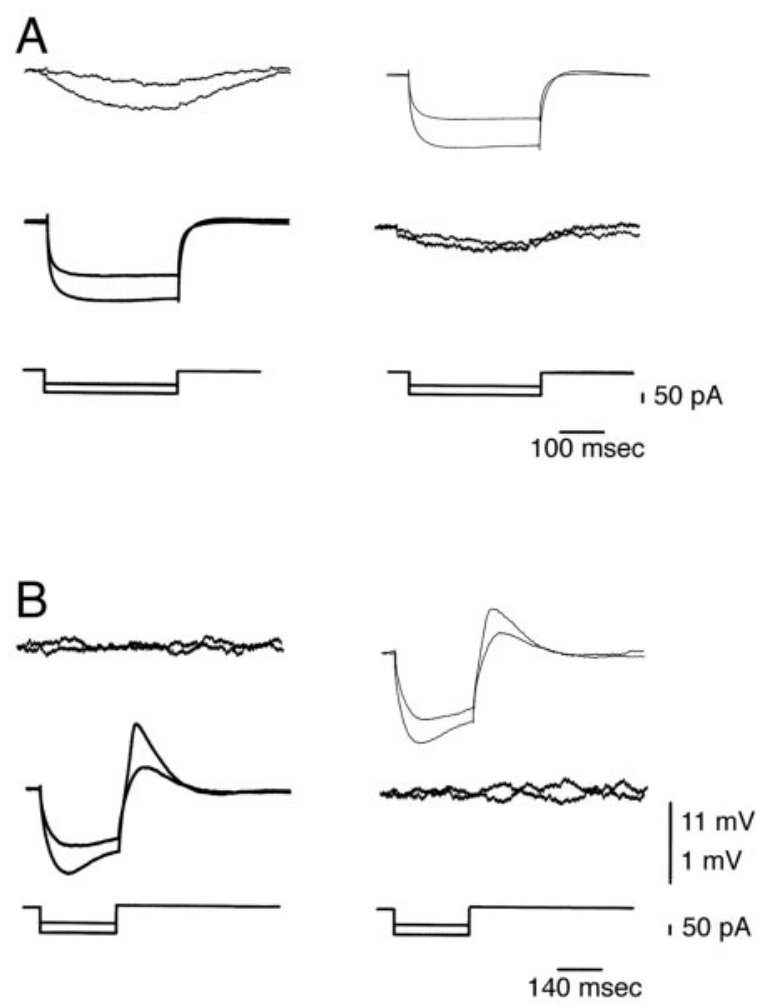

Figure 10. The absence of direct current flow between adjacent olivary neurons from knock-out mice. Dual recordings from olivary slices were performed in wild-type mice $(A)$ and knock-out mice (B). In wild-type mice, current injections into cell 1 (middle) induced direct voltage responses in cell 1 and an indirect response in cell 2 (top). This current flow was bidirectional (right), indicating that these neurons are electrotonically coupled. In knock-out mice $(B)$, indirect voltage responses were absent. 

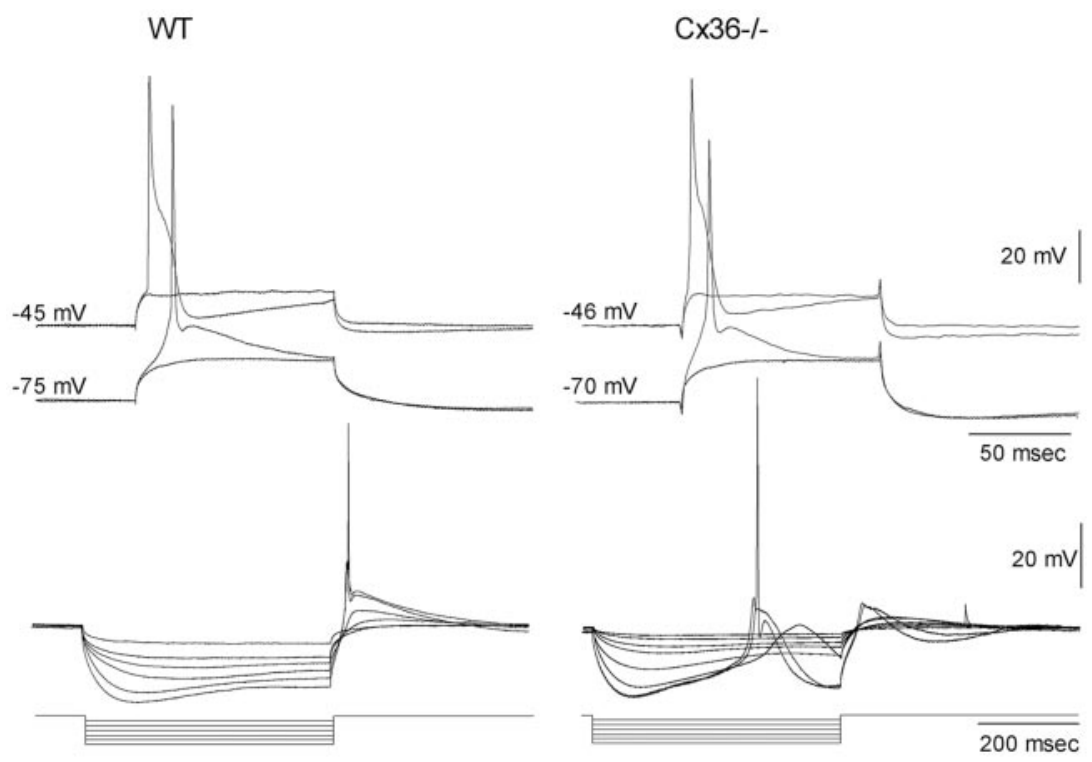

Figure 11. Olivary neurons from Cx36-deficient mice are more excitable at hyperpolarized states. Whole-cell patch recordings show the responses of olivary neurons from wild-type (WT) mice (left column) and mutant mice (right column) to depolarizing (top) and hyperpolarizing (bottom) current injections. The depolarizing pulses (top) elicited high- and low-threshold calcium responses (top and bottom traces, respectively) in both wild-type and (x36-/ - mice. The response to hyperpolarizing current steps of mutant mice is characterized by an activation of a low-threshold calcium spike that triggered a sodium-dependent action potential.

cent cell into a conditional oscillator, by either reducing its leak conductance or increasing its $\mathrm{Ca}^{2+}$ conductance (Manor et al., 1997, 2000). This finding provides a possible explanation for the changes observed in the mutant mice, which can be directly measured by voltage-clamp experiments and tested with the use of the dynamic-clamp technique.

Figure 13 shows an example of current responses in a wildtype neuron (Fig. 13A) and a knock-out neuron (Fig. 13B). The analysis of these currents is summarized in Table 1 (see Materials and Methods). The average input resistances of wild-type and mutant neurons were $86.3 \pm 20 \mathrm{M} \Omega(n=9)$ and $127.1 \pm$ $34.5 \mathrm{M} \Omega(n=9)$, respectively. A higher input resistance in the mutant neurons is expected, because the loading effect of neighboring cells is removed. Normalizing the input resistance by the surface area revealed a significantly higher specific membrane resistance $\left(R_{\mathrm{m}}\right)$ of knock-out neurons compared with wild-type neurons $(50.6 \%)$. In addition, the knock-out neurons exhibited a significantly larger peak $\mathrm{Ca}^{2+}$ current (133.7\%). The latter corresponds to an increase in current density of $0.03 \mathrm{mS} /$ $\mathrm{cm}^{2}$. In contrast, neither the $I_{\mathrm{h}}$ nor the $I_{\mathrm{AHP}}$ showed any significant changes. Thus, we conclude that knock-out neurons are characterized by an increase in $\mathrm{Ca}^{2+}$ conductances and a decrease in leak conductances. Can these differences account for the observed changes in the electrical behavior of the neurons?

\section{Dynamic clamp}

To examine this possibility, we used the dynamic-clamp technique to artificially decrease the leak conductance and increase the calcium conductance of wild-type neurons. Figure $14 A$ shows the responses of a wild-type neuron to negative current pulses. When we decreased the leak conductance by 0.2 $\mathrm{mS} / \mathrm{cm}^{2}$ (a 50\% increase in the input resistance), the amplitude of the partial repolarization was enhanced, but it was not sufficient to generate an action potential (Fig. 14A, second panel). The addition of $0.4 \mathrm{mS} / \mathrm{cm}^{2}$ calcium conductance further increased the partial repolarization and triggered a regenerative

\section{WT}

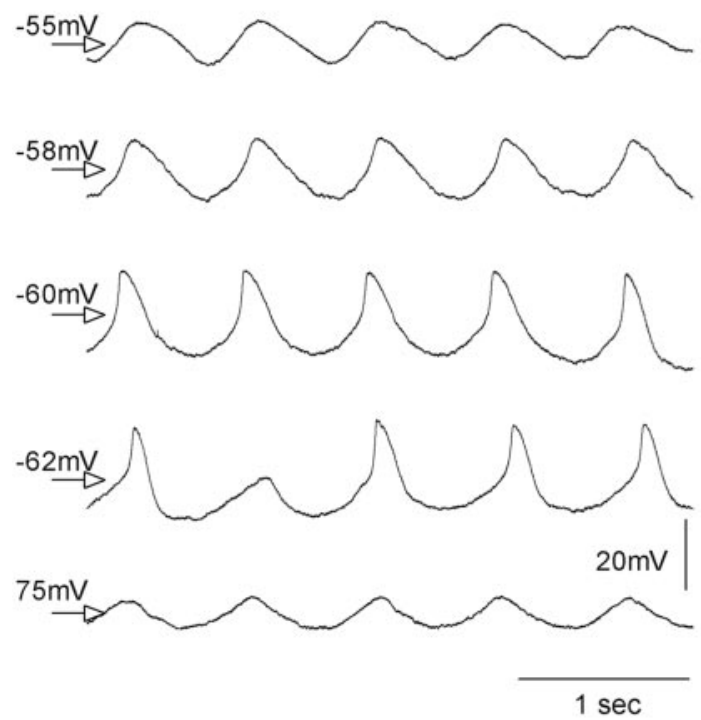

Cx36-/-

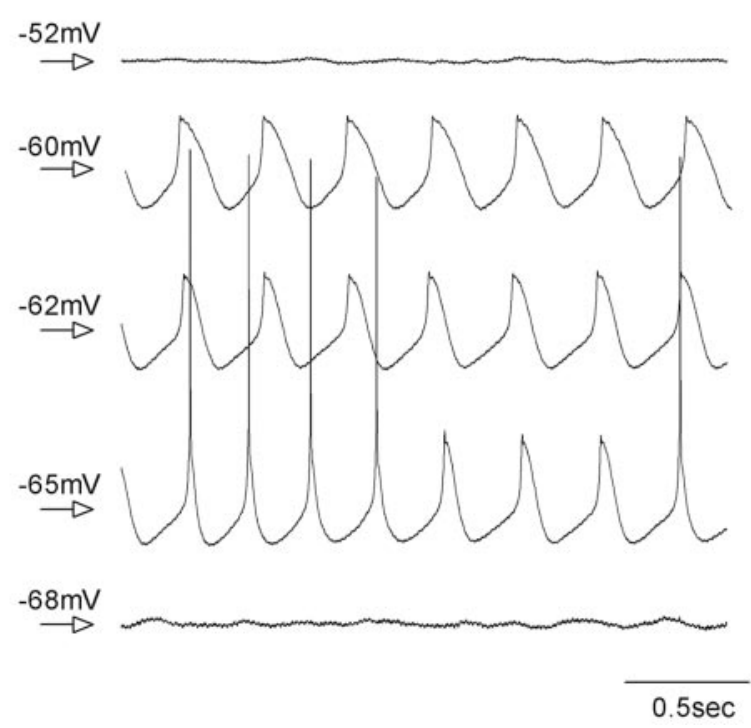

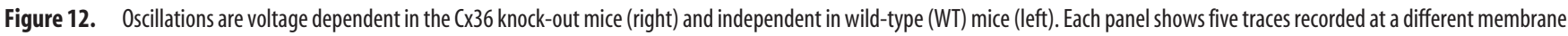
potential, which was set by DC injection. The average voltage of each trace is marked (arrow). In mutant olivary neurons, the oscillations occurred at a limited range of voltages (traces $2-4$ ), which does not include the resting potential (trace 1). In wild-type mice, the oscillations occurred at all levels of membrane potentials. 

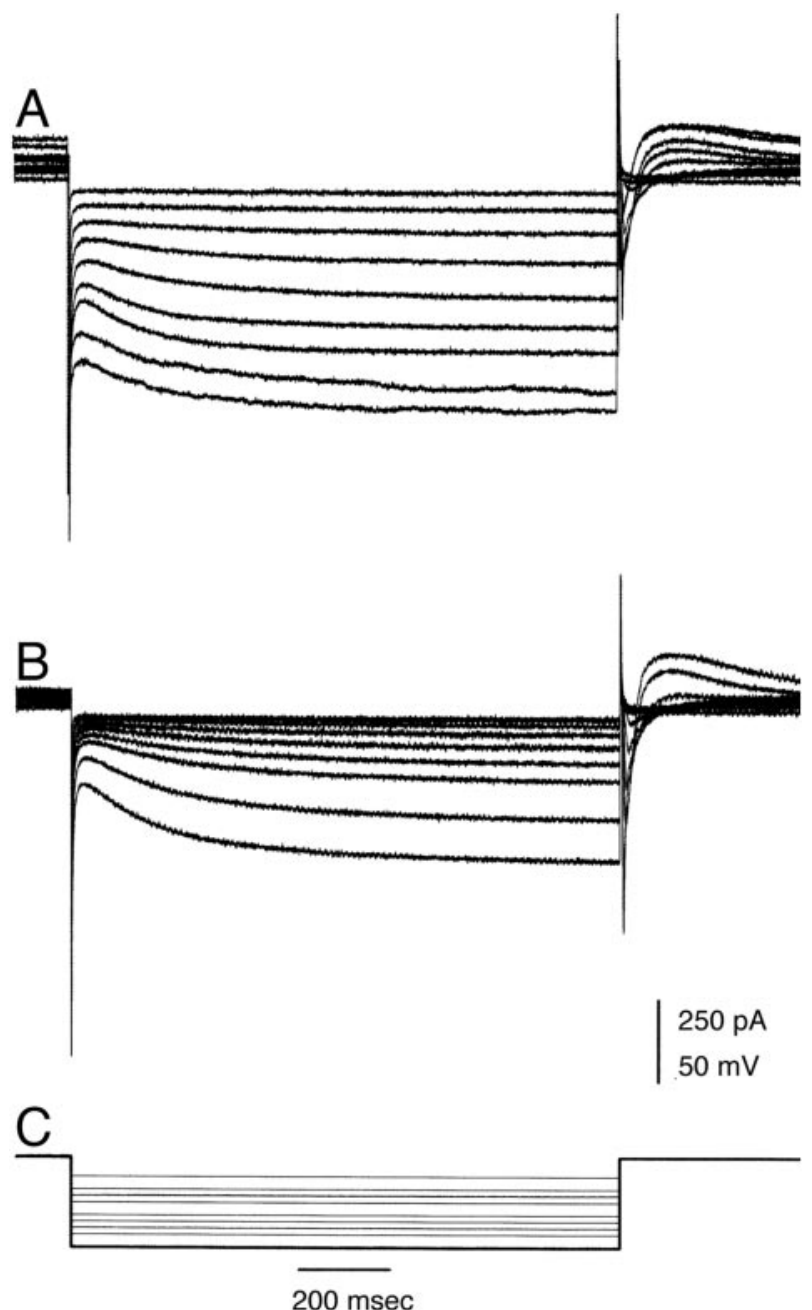

Figure 13. Current responses of wild-type and knock-out neurons to negative voltage steps. An example of the current responses of wild-type neurons $(A)$ and knock-out neurons $(B)$ to negative voltage steps is shown. Note that knock-out neurons have larger input resistance and larger calcium currents than wild-type neurons.

calcium response (third panel). An additional increase in calcium conductance to $0.9 \mathrm{mS} / \mathrm{cm}^{2}$ increased the calcium response, which at this level was sufficient to trigger a sodium-dependent action potential. Similar results were obtained when the kinetics of the low-threshold calcium conductance was modified, for example by shifting the activation curve in the hyperpolarized direction. Under these conditions, however, a much smaller increase in the low-threshold conductance was needed to mimic the knock-out phenotype.

We also examined the possibility that a wild-type cell could be transformed into a conditional oscillator by solely increasing the input resistance. Figure $14 \mathrm{~B}$ shows that this was indeed possible. However, in this case, the average increase in input resistance required for eliciting an action potential by a hyperpolarizing current pulse was $240 \%(n=9)$, five times larger than the measured difference between wild-type and mutant neurons (50\%). We conclude that a wild-type neuron in which leak conductance was decreased and calcium conductance was increased best fit the electroresponsiveness of mutant cells.

\section{Discussion}

Gap-junctional coupling and subthreshold oscillations are integral and related components of the olivary network. Yet, olivary oscillations are sustained in knock-outs of Cx36 (Long et al., 2002). Here, we show that these voltage-dependent oscillations in Cx36-deficient mice differ from those in wild-type mice, and that they are attributable to both structural and electrophysiological compensations. The structural compensations do not include a functional restoration of the gap-junction plaques but instead an increase in diameter of the proximal dendrites and a concomitant increase in surface area of the olivary neurons; the electrophysiological compensations include a decrease in leak conductance and an increase in voltage-dependent calcium conductance, leading to an increase in excitability. Thus, the absence of Cx36 triggered such compensatory mechanisms that the capacity of the uncoupled olivary neurons to produce rhythmic activity was preserved.

\section{Cytological and ultrastructural changes}

Several studies of higher brain regions, such as in the hippocampus and cerebral cortex, have demonstrated the impact of a lack of Cx36 at the cellular and systems physiological level (Deans et al., 2001; Hormuzdi et al., 2001; Schmitz et al., 2001; Spruston, 2001). To the best of our knowledge, our work is the first to demonstrate the consequences of the absence of electrical coupling at the ultrastructural level. Gap junctions of olivary neurons in wild-type mice showed the same morphological characteristics as described previously for other mammals (Sotelo et al., 1974, 1986; Rutherford and Gwyn, 1977; King et al., 1980; De Zeeuw et al., 1989, 1994). These gap junctions are predominantly located between dendritic spines within the olivary glomeruli. Each gap junction consists of a central plaque crossed by a narrow interneuronal space of $\sim 3 \mathrm{~nm}$ thickness and surrounded by attachment plaques. The cytoplasm on both sides of the plaque contains electron-dense deposits. In contrast, in Cx36 null mutants, we observed a gap-junction-like structure that resembled the normal gap junction, except for an abnormally wide interneuronal space of $\sim 9 \mathrm{~nm}$, resulting in the absence of the central plaque. Indeed, other morphological characteristics associated with gap junctions, such as the electron-dense deposits, the dendritic lamellar bodies, the distance between the attachment plaques, or the glomeruli themselves, were not affected. In heterozygous animals, normal gap-junction structures were observed; although the central plaques had a reduced diameter, uniform gap-junction-like structures were distributed throughout all olivary subnuclei. This observation is consistent with the experiments showing that all wild-type olivary neurons express Cx36 mRNA and that the entire neuropil of all olivary subnuclei shows labeled puncta after

Table 1. Electrophysiological characteristics in wild-type and knock-out mice

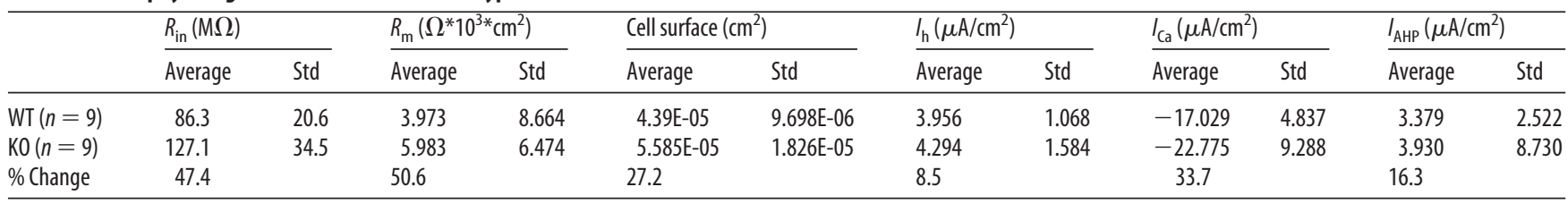

Std, Standard; WT, wild type; KO, knock-out. 


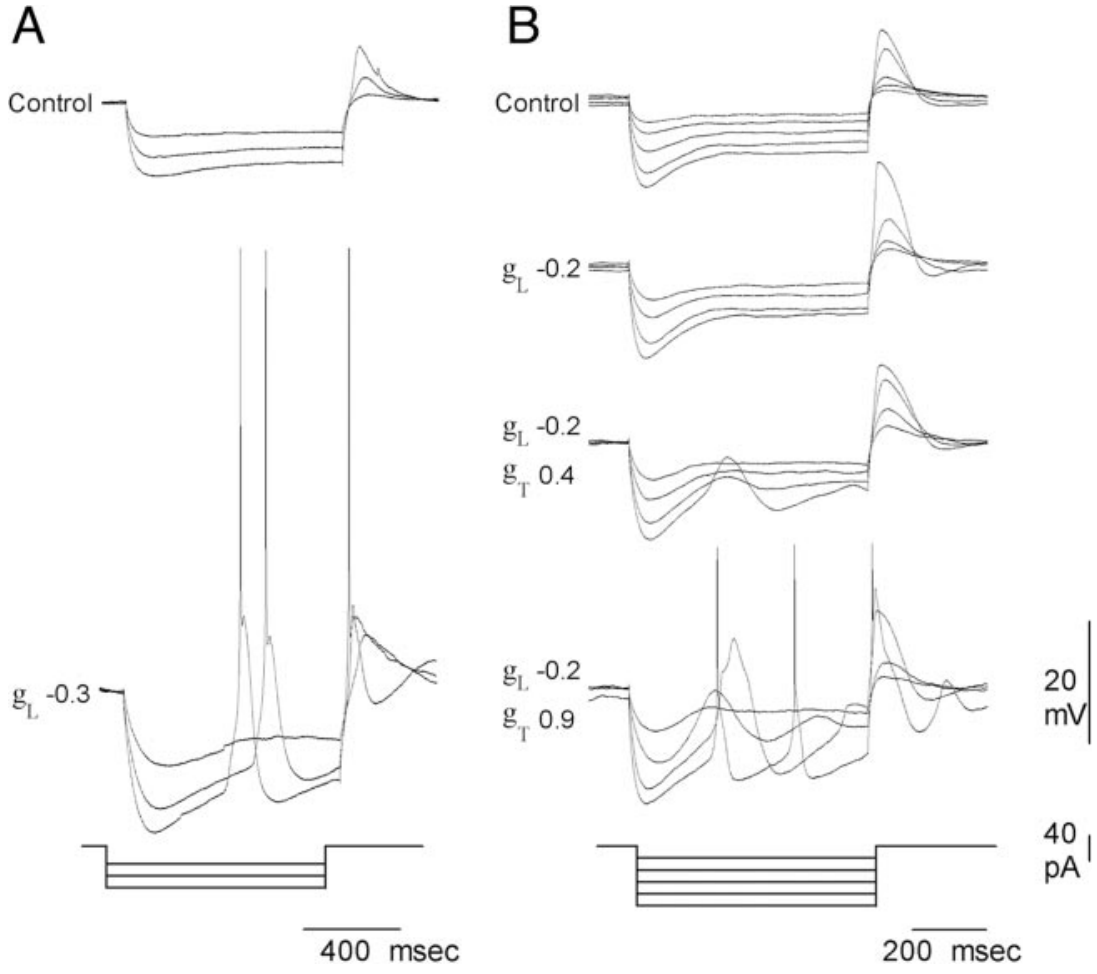

Figure 14. Changing leak and/or low-threshold calcium conductances can mimic mutant properties in wild-type mice. The dynamic-clamp technique was used to alter the leak and calcium conductances. Each panel shows the voltage response to series of negative current injections (bottom panel). The control responses are shown at the top of each panel. The responses of the dynamically clamped cell are shown below. A, Only a 200\% increase in resistance of the cell could reproduce a knock-out-like phenotype. $B$, Reducing the leak conductance by $20 \%$ is not sufficient for reproducing the mutant phenotype (i.e., increased excitability manifested as a calcium spike and action potential from a hyperpolarized state; compare top panel with the second panel). An increase in low-threshold calcium conductance enhances the sag (third panel), and an additional increment of low-threshold calcium conductance results in a low-threshold calcium spike and action potential similar to the phenotype of the mutant.

immunocytochemistry with anti-Cx36. These data diverge somewhat from those presented by Long et al. (2002), who noted that not all olivary neurons in lacZ-Cx36 mice were positively labeled. The fact that not only all cells in the wild-type mice were positively labeled in our light-microscopic labeling studies, but also that all gap junctions of the knock-out mice were affected in both our electron microscopic and electrophysiological experiments suggest to us that all olivary neurons do express Cx36. Possibly, the lacZ Cx36 mutant provides partly false negative results because of some interference with gene regulation sites (Koponen et al., 2002).

In view of the ultrastructural observations, we suggest that the gap-junction-like structures represent the sites at which gap junctions should have been formed. This leads to three conclusions: first, the site of gap-junction formation is Cx36 independent and is probably determined by the other components that form the gap-junction-like structures. Second, there is no sufficient upregulation or induction of expression of other connexin isoforms that may compensate for a lack of Cx36. Third, Cx36 is necessary for attaching the membranes of two neurons, probably via direct binding between the opposing extracellular loops of the Cx36 hemichannels. Thus, the assembly of fully operational gap junctions in the olive cannot occur without $\mathrm{Cx} 36$. This possibility was confirmed by dye-coupling experiments and paired recordings, which failed to demonstrate direct electrical coupling between olivary neurons of homozygous Cx36-/- mice.

\section{Physiological changes}

As shown by Long et al. (2002), olivary neurons of Cx36-deficient mice reveal oscillations despite the fact that they are not functionally electrotonically coupled. Yet, here we show that these oscillations are qualitatively different compared with those of the wild-type mice in that (1) they do not occur spontaneously, but are triggered by intracellular hyperpolarization; (2) they occur in a limited range of membrane potentials; and (3) their frequency depends on the membrane potential. These differences indicate that in contrast to the wildtype mutant, oscillations in the Cx36 mutant are a single-cell phenomenon. Thus, we propose that the lack of functional gap junctions induces compensatory processes that restore, at least partially, the propensity of olivary neurons to oscillate. Recently, analogous compensations have been observed in mutated neurons of the lobster stomatogastric ganglion in which a potassium conductance Shal was overexpressed (MacLean et al., 2003). This overexpression by RNA injection produced a large increase in $I_{\mathrm{A}}$ but surprisingly little change in the firing properties of the neuron. The increase in $I_{\mathrm{A}}$ was accompanied by a dramatic and linearly correlated increase in a hyperpolarizationactivated inward current $I_{\mathrm{h}}$. Thus, these results also suggest a selective coregulation of channels as a mechanism for constraining cell activity within appropriate physiological parameters.

What mechanisms could underlie the compensatory processes in the uncoupled olivary neurons? The observation that oscillations in Cx36 mutants are voltage dependent suggests that a change in the composition or type of ionic channels has occurred. Indeed, voltage-clamp experiments show that the membrane of knock-out neurons has a significantly higher specific membrane resistance and higher $\mathrm{Ca}^{2+}$ conductance. The higher membrane resistance of knock-out neurons is also inferred from the linear correlation between cell capacitance and input conductance. In addition, we found that knock-out neurons have a significantly larger membrane area. This is in contrast to the expected smaller area because of the lack of coupled neurons. However, this result is in line with our observations at both the light-microscopic and ultrastructural level, which showed that proximal dendrites are significantly thicker in mutants than in wild types. Although we did not observe any difference with respect to the length of the dendrites, we cannot exclude such an additional difference, because neither the rapid Golgi staining nor the dye coupling always completely extended into all peripheral dendrites.

The observations that knock-out neurons have both a higher input resistance and larger surface membrane point toward differences in the specific membrane properties. Using the dynamic-clamp technique, and on the basis of previous modeling studies (Manor et al., 1997, 2000), we have demonstrated that such differences are sufficient to replicate the electroresponsive properties of Cx36 mutants. It should be noted that the changes in specific membrane properties used in the dynamic-clamp experiments are larger than the measured changes between wildtype and knock-out olivary neurons. This overestimation of the 
dynamic-clamp approach is probably attributable to a technical limitation of the technique. Indeed, in the dynamic clamp we mimicked conductance changes distributed across the entire neuronal structure by injecting current in the soma. As a result of cable attenuation effects, we needed to inject large amounts of current to introduce changes to conductances that were far away from the soma. Nevertheless, this inconsistency does not detract us from our main conclusion, that such changes can transform a wild-type neuron into its knock-out variant.

An interesting question is how these changes are produced. One possibility is that the expression of a specific gene, or a group of genes, is directly regulated, for example, by changes in calcium flow. Another possibility is that in early developmental stages the olivary nucleus consists of a heterogeneous population of neurons. During maturation, a developmental process could select for a specific type of neuron that is endowed with the capability to produce oscillations at hyperpolarized membrane potentials. The advantage for selection of this type of conditional oscillators is clear, because sustained and unsynchronized oscillations are not useful for information processing. In the wild type, the occurrence and synchronization of oscillations are controlled via the extent and distribution of electrotonic coupling (Devor and Yarom, 2000). With this mechanism unavailable in mutants, regulation of rhythmic activity could be achieved by hyperpolarizing a specific subset of olivary neurons, for example by activating a common synaptic inhibitory input. Such input, if given in synchrony and with similar strength, would trigger an in-phase oscillation of identical frequency across the neurons of this subset. Regardless of the specific mechanism, the fact that compensatory processes are engaged points out the importance of these oscillations for the proper function of the olivocerebellar system.

The plasticity of the nervous system enables it to use different strategies to preserve patterns of activity under changing conditions. Here, we have demonstrated this general principle by preventing the use of electrical coupling. The system responded by choosing an alternative and novel strategy: modification of intrinsic properties of neurons.

\section{References}

Bacskai T, Matesz C (2002) Primary afferent fibers establish dye-coupled connections in the frog central nervous system. Brain Res Bull $57: 317-319$

Bal T, McCormick DA (1997) Synchronized oscillations in the inferior olive are controlled by the hyperpolarization-activated cation current $\mathrm{I}(\mathrm{h})$. J Neurophysiol 77:3145-3156.

Belluardo N, Mud G, Trovato-Salinaro A, Le Gurun S, Charollais A, SerreBeinier V, Amato G, Haefliger JA, Meda P, Condorelli DF (2000) Expression of connexin36 in the adult and developing rat brain. Brain Res 865:121-138.

Bennett MV (2002) Neoreticularism and neuronal polarization. Prog Brain Res 136:189-201.

Condorelli DF, Parenti R, Spinella F, Trovato Salinaro A, Belluardo N, Cardile V, Cicirata F (1998) Cloning of a new gap junction gene (Cx36) highly expressed in mammalian brain neurons. Eur J Neurosci 10:1202-1208.

Deans MR, Gibson JR, Sellitto C, Connors BW, Paul DL (2001) Synchronous activity of inhibitory networks in neocortex requires electrical synapses containing connexin 36. Neuron 31:477-485.

Devor A, Yarom Y (2000) GABAergic modulation of olivary oscillations. Prog Brain Res 124:213-220.

Devor A, Yarom Y (2002a) Electrotonic coupling in the inferior olivary nucleus revealed by simultaneous double patch recordings. J Neurophysiol 87:3048-3058.

Devor A, Yarom Y (2002b) Generation and propagation of subthreshold waves in a network of inferior olivary neurons. J Neurophysiol 87:3059-3069.

De Zeeuw CI, Holstege JC, Ruigrok TJ, Voogd J (1989) Ultrastructural study of the GABAergic, cerebellar, and mesodiencephalic innervation of the cat medial accessory olive: anterograde tracing combined with immunocytochemistry. J Comp Neurol 284:12-35.

De Zeeuw CI, Wylie DR, DiGiorgi PL, Simpson JI (1994) Projections of individual Purkinje cells of identified zones in the flocculus to the vestibular and cerebellar nuclei in the rabbit. J Comp Neurol 349:428-447.

De Zeeuw CI, Hertzberg EL, Mugnaini E (1995) The dendritic lamellar body: a new neuronal organelle putatively associated with dendrodendritic gap junctions. J Neurosci 15:1587-1604.

De Zeeuw CI, Hoogenraad CC, Goedknegt E, Hertzberg E, Neubauer A, Grosveld F, Galjart N (1997) CLIP-115, a novel brain specific cytoplasmic linker protein, mediates the localisation of dendritic lamellar bodies. Neuron 19:1187-1199.

De Zeeuw CI, Simpson JI, Hoogenraad CC, Galjart N, Koekkoek SKE, Ruigrok TJH (1998) Microcircuitry and function of the inferior olive. Trends Neurosci 21:391-400.

Gueldenagel M, Ammermuller J, Feigenspan A, Teubner B, Degen J, Sohl G, Willecke K, Weiler R (2001) Visual transmission deficits in mice with targeted disruption of the gap junction gene connexin 36. J Neurosci 21:6036-6044.

Hinrichsen CF, Larramendi LM (1968) Synapses and cluster formation of the mouse mesencephalic fifth nucleus. Brain Res 7:296-299.

Hormuzdi SG, Pais I, LeBeau FE, Towers SK, Rozov A, Buhl EH, Whittington MA., Monyer H (2001) Impaired electrical signaling disrupts gamma frequency oscillations in connexin 36 deficient mice. Neuron 31:487-495.

Ivry RB (1996) The representation of temporal information in perception and motor control. Curr Opin Neurobiol 6:851-857.

King JS (1980) The synaptic organization of the inferior olivary nucleus. In: The inferior olivary nucleus (Courville J, De Montigny C, Lammare Y, eds), pp 1-35. New York: Raven.

Kistler WM, van Hemmen JL, De Zeeuw CI (2000) Time window control: a model for cerebellar function based on synchronization, reverberation, and time slicing. In: Cerebellar modules: molecules, morphology, and function (De Zeeuw CI, Ruigrok TJH, Gerrits NGM, eds), pp 275-299. Amsterdam: Elsevier.

Kistler WM, De Jeu MTG, Elgersma Y, van der Giessen RS, Hensbroek R, Luo C, Koekkoek SKE, Hoogenraad CC, Hamers FPT, Gueldenagel M, Sohl G, Willecke K, De Zeeuw CI (2002) Analysis of Cx36 knock out does not support tenet that olivary gap junctions are required for complex spike synchronization and normal motor performance. Ann NY Acad Sci 978:391-405.

Koponen JK, Turunen AM, Yla-Herttuala S (2002) Escherichia coli DNA contamination in AmpliTaq gold polymerase interferes with TaqMan analysis of lacZ. Mol Ther 5:220-222.

Lampl I, Yarom Y (1993) Sub-threshold oscillations of the membrane potential: a functional synchronizing and timing device. J Neurophysiol 70:2181-2186.

Lampl I, Yarom Y (1997) Sub-threshold oscillations and resonant behavior: two manifestations of the same mechanism. Neuroscience 78:325-341.

Landis DMD, Reese TS, Raviola E (1974) Differences in membrane structure between excitatory and inhibitory components of the reciprocal synapse in the olfactory bulb. J Comp Neurol 155:67-92.

Lang EJ (2001) Organization of olivocerebellar activity in the absence of excitatory glutamatergic input. J Neurosci 21:1663-1675.

Llinás R, Yarom Y (1981a) Electrophysiology of mammalian inferior olivary neurones in vitro. Different types of voltage-dependent ionic conductances. J Physiol (Lond) 315:549-567.

Llinás R, Yarom Y (1981b) Properties and distribution of ionic conductances generating electroresponsiveness of mammalian inferior olivary neurons in vitro. J Physiol (Lond) 315:569-584.

Llinás R, Yarom Y (1986) Oscillatory properties of guinea-pig inferior olivary neurones and their pharmacological modulation: an in vitro study. J Physiol (Lond) 376:163-182.

Llinás R, Yarom Y (1987) Long-term modifiability of anomalous and delayed rectification in guinea pig inferior olivary neurons. J Neurosci 7:1166-1177.

Loewenstein Y, Yarom Y, Sompolinsky H (2001) The generation of oscillations in networks of electrically coupled cells. Proc Natl Acad Sci USA 98:8095-8100.

Long MA, Deans MR, Paul DL, Connors BW (2002) Rhythmicity without synchrony in the electrically uncoupled inferior olive. J Neurosci 22:10898-10905.

MacLean JN, Zhang Y, Johnson BR, Harris-Warrick RM (2003) Activity- 
independent homeostasis in rhythmically active neurons. Neuron 37:109-120.

MacVicar BA, Dudek FE (1981) Electrotonic coupling between pyramidal cells: a direct demonstration in rat hippocampal slices. Science 213:782-785.

Maier N, Guldenagel M, Sohl G, Siegmund H, Willecke K, Draguhn A (2002) Reduction of high-frequency network oscillations (ripples) and pathological network discharges in hippocampal slices from connexin 36-deficient mice. J Physiol (Lond) 541:521-528.

Manor Y, Rinzel J, Segev I, Yarom Y (1997) Low-amplitude oscillations in the inferior olive: a model based on electrical coupling of neurons with heterogeneous channel densities. J Neurophysiol 77:2736-2752.

Manor Y, Yarom Y, Chorev E, Devor A (2000) To beat or not to beat: a decision taken at the network level. J Physiol (Lond) 94:375-390.

Matsumoto A, Arnold AP, Zampighi GA, Micevych PE (1988) Androgenic regulation of gap junctions between motoneurons in rat spinal cord. J Neurosci 8:4177-4183.

Peters A (1980) Morphological correlates of epilepsy: cells in the cerebral cortex. Adv Neurol 27:21-48.

Rash JE, Staines WA, Yasumura T, Patel D, Furman CS, Stelmack GL, Nagy JI (2000) Immunogold evidence that neuronal gap junctions in adult rat brain and spinal cord contain connexin-36 but not connexin-32 or connexin-43. Proc Natl Acad Sci USA 97:7573-7578.

Raviola E, Gilula NB (1975) Intramembrane organization of specialized contacts in the outer plexiform layer of the retina. A freeze-fracture study in monkeys and rabbits. J Cell Biol 65:192-222.

Rutherford JG, Gwyn DG (1977) Gap junctions in the inferior olivary nucleus of the squirrel monkey, Saimiri sciureus. Brain Res 128:374-378.

Schmitz D, Schuchmann S, Fisahn A, Draguhn A, Buhl EH, Petrasch-Parwez E, Dermietzel R, Heinemann U, Traub RD (2001) Axo-axonal coupling: a novel mechanism for ultrafast neuronal communication. Neuron 31:831-840.

Sharp AA, O’Neil MB, Abbott LF, Marder E (1993) Dynamic clamp: computer-generated conductances in real neurons. J Neurophysiol 69:992-995.

Sotelo C, Llinás RR (1972) Specialized membrane junctions between neurons in the vertebrate cerebellar cortex. J Cell Biol 53:271-289.

Sotelo C, Llinás R, Baker R (1974) Structural study of inferior olivary nucleus of the cat: morphological correlates of electrotonic coupling. J Neurophysiol 37:541-559.

Sotelo C, Gotow T, Wassef M (1986) Localization of glutamic-aciddecarboxylase-immunoreactive axon terminals in the inferior olive of the rat, with special emphasis on anatomical relations between GABAergic synapses and dendrodendritic gap junctions. J Comp Neurol 252:32-50.

Spruston N (2001) Axonal gap junctions send ripples through the hippocampus. Neuron 31:669-671.

Teubner B, Degen J, Sohl G, Guldenagel M, Bukauskas FF, Trexler EB, Verselis VK, De Zeeuw CI, Lee CG, Kozak CA, Petrasch-Parwez E, Dermietzel R, Willecke K (2000) Functional expression of the murine connexin 36 gene coding for a neuron-specific gap junctional protein. J Membr Biol 176:249-262.

Van Pelt J, Uylings HB, Verwer RW, Pentney RJ, Woldenberg MJ (1992) Tree asymmetry-a sensitive and practical measure for binary topological trees. Bull Math Biol 54:759-784.

Voogd J, Bigaré F (1980) Topographical distribution of olivary and corticonuclear fibers in the cerebellum. A review. In: The inferior olivary nucleus (Courville J, De Montigny C, Lamarre Y, eds), pp 207-235. New York: Raven.

Welsh JP, Lang EJ, Sugihara I, Llinás R (1995) Dynamic organization of motor control within the olivocerebellar system. Nature 374:453-457.

Yarom Y (1991) Rhythmogenesis in a hybrid system-interconnecting an olivary neuron to an analog network of coupled oscillators. Neuroscience 44:263-275.

Yarom Y, Cohen D (2002) The olivocerebellar system as a generator of temporal patterns. Ann NY Acad Sci 978:122-134. 